\title{
Effect of cimetidine premedication on morphine-induced ventilatory depression
}

The potential respiratory interacion between morphine and cimetidine was studied by determining resting ventilation, $P$ ETCO $\mathrm{O}_{2}$ and ventilatory response to added carbon dioxide in eight healthy volunteers on three separate occasions following administration of: (1) cimetidine $600 \mathrm{mg}$ p.o., (2) morphine $10 \mathrm{mg} \mathrm{IM}$. (3) morphine $10 \mathrm{mg} / \mathrm{M}$ preceded by cimetidine $600 \mathrm{mg}$ p.o. Individual entry into the study was randomized and separated by at least one week. All measurements were determined at time $0,30,60,120,180,240,360,480,600,720$ minutes and at the end of 24 hours, In addition, serum morphine levels were measured in six subjects during the first six hours following morphine administration. Cimetidine alone had negligible respiratory effects. Morphine alone reduced resting ventilation, elevated $P E T C O_{2}$ and rediced the ventilatory response to added $\mathrm{CO}_{2}$, while the morphinecimetidine combination caused a more profound depression of the $\mathrm{CO}_{2}$ response and delay in its recovery. No significant difference between resting ventilation and $\mathrm{PETCO}_{2}$ was observed. We conclude that cimetidine premedication interacts with morphine to prolong the respiratory depression but the magnitude of this interaction is small and clinically insignificant in healthy subjects. Caution, however, should be exercised in susceptible pasients.

\section{Key words}

ANALGESICS: morphine; PREMEDICATION: cimetidine; VENTILATION: carbon dioxide response; INTERACTIONS (DRUGS): morphine, cimetidine.

From the Department of Anaesthesia, University Hospital and University of Westem Ontario, London.

Supported in part by a Grant from Smith, Kline and French, Canada Limited.

Address correspondence to: A.M. Lam MD, Department of Anaesthesia, University Hospital, P.O. Box 5339, Postal Stn. A., London, Canada N6A. 5A5.
Cimetidine, an effective histamine $\mathrm{H}_{2}$ antagonist, is widely used in the treatment of peptic disease and hypersecretory syndromes.' The effectiveness of cimetidine premedication in reducing gastric acidity and therefore the risk of acid aspiration, has also been demonstrated in elective surgical patients, ${ }^{2,3}$ and obstetrical patients. ${ }^{4}$ As a result, an increasing proportion of surgical patients confronting the anaesthetist is on acute or chronic cimetidine therapy. While the drug was initially thought to be free of side-effects, a recent pharmacokinetic study indicated that cimetidine therapy is associated with a reduction in liver blood flow. ${ }^{5}$ In addition, cimetidine can inhibit the hepatic microsomal cytochrome enzyme system ${ }^{6}$ which is responsible for the metabolism of a varicty of drugs. ${ }^{7-9}$ Thus, cimetidine can exaggerate as well as prolong the therapeutic effects of concurrently administered intravenous propranolol. ${ }^{s}$

As elimination of morphine is largely dependent on hepatic clearance, ${ }^{10}$ cimetidine may have a similar interaction with morphine. While prolongation of analgesia can be considered desirable, exaggeration of the accompanied respiratory depression is clearly not. Indeed, this potential interaction had been implicated as the cause of profound respiratory depression in a patient on concurrent cimetidine and opiate therapy. ${ }^{11}$ The purpose of this investigation was to assess the interaction between cimetidine and morphine in humans by studying morphine-induced respiratory depression with and without cimetidine pre-treatment. In addition, to rule out a pharmacodynamic interaction, the respiratory effect of cimetidine pre-medication alone was also studied.

\section{Methods}

The protocol for this study was approved by the Health Sciences Standing Committee on Human 
Research at the University of Western Ontario. Each subject gave written consent to participate, after being informed of the nature of the proposed study and the risks involved. Eight healthy volunteers (seven males, one female) were studied. Their mean age was $32.1 \pm 6.0$ (S.D.), weight $70.9 \pm 8.80$ (S.D.) $\mathrm{kg}$, height $172.63 \pm 9.26 \mathrm{~cm}$ and surfacc area $1.84 \pm 0.15 \mathrm{sq} \mathrm{m}$ (S.D.).

In a randomized order, all subjects were studied three times; (I) following administration of morphine $10 \mathrm{mg}$ IM alone; (II) oral cimetidine $600 \mathrm{mg}$ one hour preceding the administration of morphine $10 \mathrm{mg} \mathrm{IM}$; (III) following oral cimetidine $600 \mathrm{mg}$ alone. Individual study was separated by at least one week. To rule out hepatic and renal influences on drug elimination, liver enzymes and renal function, as indicated by biochemical indices were determined in all subjects before commencement of the study. Owing to the subjective experience of increased drowsiness with the morphine-cimetidine combination in the first four subjects, the study with the last four was carried out in a double-blind manner. The placebo tablets were supplied by Smith, Kline and French, Canada Limited.

All subjects were receiving no medications and refrained from taking caffeine-containing substances on the day of study. All subjects were positioned supine. The study began when the subject became accustomed to the nose-clip and breathing through the mouthpiece connected to a non-rebreathing valve. In all three study states, serial resting ventilation, end-tida $\mathrm{CO}_{2}$ and the ventilatory response to added $\mathrm{CO}_{2}$ were determined at times zero (immediately prior to morphine administration in study states I and $\mathrm{I}$, and one hour following oral cimetidine in study state III), $30,60,120,240,360,480,720$ minutes and at the end of twenty-four hours. In six subjects, $10 \mathrm{ml}$ of venous blood was also withdrawn for determination of serum morphine concentration at times zero, 15, 30, 60, 120, 240 and 360 minutes. Subjects were allowed normal activity between study periods.

End-tidal $\mathrm{CO}_{2}$ was determined with a PerkinElmer \#1100 mass spectrometer, which was calibrated each testing day with Canadian Liquid Air specialty gases. Values of end-tidal concentrations were then converted to tensions, using the measured barometric pressure of each testing day. Inspired ventilation was recorded by pneumotachography by incorporating the Fleisch pneumotachograph head in the inspiratory limb of the circuit. The integrated signal was calibrated regularly with an air calibration syringe. Each value of resting ventilation was the average of a one minute recording of ventilation. The ventilatory response to added $\mathrm{CO}_{2}$ was determined using Read's rebreathing method as described in a previous communication. ${ }^{12}$ Essentially, with the nose-clip on and using a mouthpiece, the subject was connected to a total rebreathing circuit previously primed with $\mathrm{CO}_{2}$ (seven per cent). The subject was then instructed to inhale three large breaths from this circuit, the purpose of which was to achieve rapid equilibration, and following this, the subject was allowed to rebreathe and thereby accumulate $\mathrm{CO}_{2}$. The end-tidal $\mathrm{CO}_{2}$ concentration usually increased by 2.0 to 2.5 per cent before the test was terminated. Values of instantaneous ventilation during the $\mathrm{CO}_{2}$ response were the averages of at least three consecutive breaths. To analyze ventilatory response to added $\mathrm{CO}_{2}$, we assumed a linear relationship between ventilation and end-tidal $\mathrm{CO}_{2}$, and computed the slope and the intercept of the least squares linear regression. Volumes of ventilation were expressed at B.T.P.S., and to take into consideration the difference in weight and height among the subjects, both the resting ventilation and the $\mathrm{CO}_{2}$ response slope were corrected for body surface area.

The venous blood samples were immediately centrifuged, the serum separated and kept frozen at $-70^{\circ} \mathrm{C}$ until the time of analysis.

Serum morphine levels were analyzed using high performance liquid chromatography with electrochemical detection. The system consisted of a chromatographic pump (Altex 110A), loop injector valve (Rheodyne 7120), reverse face column (Altex ultrasil-octyl 10 micrometer), and a glassy carbon electro-detector cell with controller (Bioanalytical Systems LC2A). Separations were performed isocratically at a flow rate of $1 \mathrm{ml} \cdot \mathrm{min}^{-1}$ with a mobile phase to 60 per cent methanol and 40 per cent $0.025 \mathrm{M}$ potassium dihydrogen phosphate $(\mathrm{pH} 6.0)$. The working electrode was set at a potential of $+0.9 \mathrm{~V}$. Peak areas were quantified using a recording integrator (Hewlett-Packard 3380A). For sample preparation, the internal standard dihydromorphone ( $40 \mathrm{ng}$ ), was added to serum ( 500 microlitre) along with bicarbonate buffer (pH 8.9, 100 microlitre) and isopropyl alcohol in ethyl acetate $(2: 98,750$ microlitre). This mixture was vortexed (ten seconds) and 
TABLE I Resting ventilation $\left(\mathrm{L} \cdot \mathrm{min}^{-1} \cdot \mathrm{m}^{-2}\right)$

\begin{tabular}{|c|c|c|c|c|c|c|c|c|c|c|c|}
\hline & 0 & $30 \mathrm{~min}$ & $60 \min$ & 120 min & $180 \min$ & $240 \min$ & $360 \mathrm{~min}$ & $480 \mathrm{~min}$ & $600 \mathrm{~min}$ & $720 \mathrm{~min}$ & $24 \mathrm{hr}$ \\
\hline Morphine $\dagger$ & 4.62 & $3.94^{*}$ & $3.70^{*}$ & $3.11^{*}$ & $3.13^{*}$ & $3.12^{*}$ & $3.34 *$ & $3.45^{*}$ & 4.51 & 4.41 & 4.40 \\
\hline alone & \pm 0.18 & \pm 0.24 & \pm 0.18 & \pm 0.29 & \pm 0.22 & \pm 0.24 & \pm 0.23 & \pm 0.36 & \pm 0.29 & \pm 0.22 & \pm 0.30 \\
\hline $\begin{array}{l}\text { Morphine } \dagger, \ddagger \\
\text { pretreatment }\end{array}$ & 4.04 & $3.11^{*}$ & $3.11^{*}$ & $2.83^{*}$ & $2.82 *$ & $2.89 *$ & $3.08 *$ & $3.06^{*}$ & 3.68 & 3.74 & 4.01 \\
\hline with cimetidine & \pm 0.26 & \pm 0.21 & \pm 0.25 & \pm 0.28 & \pm 0.26 & \pm 0.19 & \pm 0.28 & \pm 0.29 & \pm 0.28 & \pm 0.31 & \pm 0.24 \\
\hline $\begin{array}{l}\text { Cimetidine } \\
\text { alone }\end{array}$ & $\begin{array}{r}3.85 \\
\pm 0.18\end{array}$ & $\begin{array}{r}3.55 \\
\pm 0.20\end{array}$ & $\begin{array}{r}3.94 \\
\pm 0.28\end{array}$ & $\begin{array}{r}3.50 \\
\pm 0.19\end{array}$ & $\begin{array}{r}4.00 \\
\pm 0.13\end{array}$ & $\begin{array}{r}3.91 \\
\pm 0.21\end{array}$ & $\begin{array}{r}3.97 \\
\pm 0.26\end{array}$ & $\begin{array}{r}4.20 \\
\pm 0.12\end{array}$ & $\begin{array}{r}4.46 \\
\pm 0.12\end{array}$ & $\begin{array}{r}4.58 \\
\pm 0.32\end{array}$ & $\begin{array}{r}4.57 \\
\pm 0.31\end{array}$ \\
\hline
\end{tabular}

All values means \pm S.E.M.

*Significantly different from control (ỉme 0 ) ( $p<0.05$ ) (Dunnett's Test).

$\dagger$ Significantly different from cimetidine alone ( $p<0.05$, analysis of variance)

+Significantly different from morphine alone ( $p<0.05$, analysis of variance).

centrifuged. The organic layer was then transferred to a tube containing $0.01 \mathrm{M}$ hydrochloric acid (100 microlitre) and vortexed again. After centrifugation the organic layer was aspirated off and the remaining aqueous layer injected into the chromatugraph. Serum concentrations were obtained by comparison to a standard curve prepared from extracted samples containing known amounts of morphine and internal standard.

Because of the known day-to-day variation of $\mathrm{CO}_{2}$ response within the same individual, ${ }^{13}$ the recovery ratio (ratio of observed $\mathrm{CO}_{2}$ response slope to control slope at time zeto), rather than the absolute value, was used for statistical computation. For comparison of the recovery ratio $\left(\mathrm{CO}_{2}\right.$ response), resting ventilation and end-tidal $\mathrm{CO}_{2}$, analysis of variance for repeated measurements in a packaged computer program (BMDP) was used. For comparison to the control measurements (time 0) within each group, Dunnett's test was used. A p value of $<0.05$ was considered statistically significant. The mean serum morphine concentrations of the six subjects were plotted on a natural logarithmic scale against time and the slopes were computed using the least squares linear regression analysis. Assuming complete absorption of morphine, this slope represents the rate of decline of morphine concentration and comparison was made between the slopes obtained during the two study states I and II.

\section{Results}

All subjects had normal liver enzymes and renal function. Except for two subjects who experienced nausea and vomiting following morphine administration, there were no complications. All subjects felt sedated following the administration of morphine, while no effects were noted with cimetidine alone. The first four subjects felt subjectively that they were more sedated with the morphine-cimetidine combination. To clarify this, the study in the last four subjects was carried out in a double-blind manner using placebo. Based on the subjective experience, all four subjects correctly identified the study occasion on which they had received cimetidine.

The principal observations of the study are tabulated in Tables I, II and III. There was considcrable variation within the subjects on different study occasions in resting ventilation and $\mathrm{CO}_{2}$ response. Cimetidine alone had no significant effect on resting ventilation, end-tidal $\mathrm{CO}_{2}$, or the $\mathrm{CO}_{2}$ response, although it appeared to transiently decrease the resting ventilation at 30 minutes. Morphine alone reduced resting ventilation, increased end-tidal carbon dioxide, displaced the $\mathrm{CO}_{2}$ response curve to the right and reduced the slope. These effects peaked at approximately 120 minutes and thereafter gradually returned to normal with full recovery evident at the end of 12 hours. The morphine-cimetidine combination had similar effects on resting ventilation, end-tidal $\mathrm{CO}_{2}$, and the $\mathrm{CO}_{2}$ response curve, but in contrast to the study with morphine alone, the depression of the $\mathrm{CO}_{2}$ response slope was more profound and lasted longer (Table III). The difference in the recovery ratio between the time period 240 to 720 minutes was statistically significant with a $\mathrm{p}$ value less than 0.05 (Figure 1). In addition, a difference in resting ventilation throughout the 
TABLE II PetCO

\begin{tabular}{|c|c|c|c|c|c|c|c|c|c|c|c|c|}
\hline & & 0 & $30 \mathrm{~min}$ & $60 \mathrm{~min}$ & $120 \min$ & $380 \mathrm{~min}$ & $240 \min$ & $360 \mathrm{~min}$ & $480 \mathrm{~min}$ & $600 \mathrm{~min}$ & $720 \min$ & $24 h r$ \\
\hline $\begin{array}{l}\text { Morphine } \\
\text { alone }\end{array}$ & $\begin{array}{l}(\mathrm{kPa}) \\
(\mathrm{mmHg})\end{array}$ & $\begin{array}{r}5.47 \\
41.1 \\
\pm 0.7\end{array}$ & $\begin{aligned} & 5.55 \\
& 41.7 \\
& \pm 1.1\end{aligned}$ & $\begin{array}{r}5.80 \\
43.6^{*} \\
\pm 0.8\end{array}$ & $\begin{array}{r}5.88 \\
44.2^{*} \\
\pm 0.9\end{array}$ & $\begin{aligned} & 5.89 \\
& 44.3^{*} \\
& \pm 0.9\end{aligned}$ & $\begin{array}{r}5.91 \\
44.4^{*} \\
\pm 0.7\end{array}$ & $\begin{array}{r}5.91 \\
44.4^{*} \\
\pm 0.8\end{array}$ & $\begin{array}{r}5.80 \\
43.6^{*} \\
\pm 0.9\end{array}$ & $\begin{array}{r}5.67 \\
42.6^{*} \\
\pm 0.9\end{array}$ & $\begin{aligned} & 5.64 \\
& 42.4^{*} \\
& \pm 1.0\end{aligned}$ & $\begin{array}{r}5.57 \\
41.9 \\
\pm 0.8\end{array}$ \\
\hline $\begin{array}{l}\text { Morphine } \\
\text { plus } \\
\text { pretreatment } \\
\text { with } \\
\text { cimetidine }\end{array}$ & $\begin{array}{l}(\mathrm{kPa}) \\
(\mathrm{mmHg})\end{array}$ & $\begin{array}{r}40.8 \\
\pm 0.9\end{array}$ & $\begin{array}{r}42.0 \\
\pm 0.9\end{array}$ & $\begin{array}{l}42.6^{*} \\
=1.1\end{array}$ & $\begin{aligned} & 43.5^{*} \\
\pm & 1.1\end{aligned}$ & $\begin{array}{l}43.8^{*} \\
\pm 1.0\end{array}$ & $\begin{array}{l}43.5^{*} \\
\pm 0.8\end{array}$ & $\begin{array}{l}44.1^{*} \\
\pm 1.0\end{array}$ & $\begin{array}{l}43.6^{*} \\
\pm 0.9\end{array}$ & $\begin{array}{l}43.8^{*} \\
\pm 1.0\end{array}$ & $\begin{array}{l}43.0^{*} \\
\pm 0.8\end{array}$ & $\begin{array}{r}5.52 \\
41.5 \\
\pm 1.0\end{array}$ \\
\hline $\begin{array}{l}\text { Cinetidine } \\
\text { alone }\end{array}$ & $\begin{array}{l}(\mathrm{kPa}) \\
(\mathrm{mmHg})\end{array}$ & $\begin{array}{r}5.41 \\
40.7 \\
\pm 0.8\end{array}$ & $\begin{array}{c}5.43 \\
40.8 \\
\pm 0.9\end{array}$ & $\begin{array}{r}5.40 \\
40.6 \\
+0.8\end{array}$ & $\begin{array}{c}5.35 \\
40.2 \\
+1.0\end{array}$ & $\begin{array}{c}5.35 \\
40.2 \\
+1.0\end{array}$ & $\begin{aligned} & 5.40 \\
& 40.6 \\
& \pm 0.9\end{aligned}$ & $\begin{array}{c}5.44 \\
40.9 \\
\pm 0.8\end{array}$ & $\begin{array}{l}5.40 \\
40.6 \\
+0.9\end{array}$ & $\begin{array}{c}5.40 \\
40.6 \\
+1.0\end{array}$ & $\begin{array}{c}5.44 \\
40.9 \\
+1.0\end{array}$ & $\begin{array}{r}5.47 \\
41.1 \\
+0.9\end{array}$ \\
\hline
\end{tabular}

All values means \pm S.E.M.

*Significantly different from control (time 0) ( $\mathrm{p}<0.05$, Dunnett's Test)

$\dagger$ Significantly different from cimetidine alone $(p<0.05$, analysis of variance).

TABLE III $\mathrm{CO}_{2}$ response slope

\begin{tabular}{|c|c|c|c|c|c|c|c|c|c|c|c|}
\hline & 0 & 30 min & $60 \min$ & $120 \min$ & 180 mint & $240 \mathrm{~min}$ & $360 \mathrm{~min}$ & $480 \mathrm{~min}$ & $600 \mathrm{~min}$ & $720 \mathrm{~min}$ & $24 \mathrm{hr}$ \\
\hline \multicolumn{12}{|l|}{ Morphine alonet } \\
\hline$\left(\mathrm{L} \cdot \mathrm{min}^{-1} \cdot \mathrm{kPa}^{-1}-\mathrm{m}^{-2}\right)$ & $\begin{array}{r}9.0 \\
\pm 1.5\end{array}$ & $\begin{array}{r}0.8 \\
\pm 0.8\end{array}$ & $\begin{array}{r}0.8 \\
\pm 0.8\end{array}$ & $\begin{array}{r}0.0 \\
\pm 1.5\end{array}$ & $\begin{array}{r}0.0 \\
\pm 1.5\end{array}$ & $\begin{aligned} & 0.0 \\
\pm & 1.5\end{aligned}$ & $\begin{aligned} & 0.8 \\
= & 1.5\end{aligned}$ & $=0.8$ & $=1.5$ & $\begin{array}{r}6.5 \\
\pm 1.5\end{array}$ & $\begin{array}{r}9.8 \\
\pm 0.8\end{array}$ \\
\hline \multirow[t]{2}{*}{$\left(\mathrm{L} \cdot \mathrm{min}^{-1} \cdot \mathrm{mmHg}^{-1} \cdot \mathrm{m}^{-2}\right)$} & 1.2 & 0.9 & 0.9 & $0.8^{*}$ & $0.8^{*}$ & $0.8^{*}$ & 0.9 & 1.0 & 1.0 & 1.1 & 1.3 \\
\hline & \pm 0.2 & \pm 0.1 & \pm 0.1 & \pm 0.2 & \pm 0.2 & \pm 0.2 & \pm 0.2 & \pm 0.1 & \pm 0.2 & \pm 0.2 & \pm 0.1 \\
\hline \multicolumn{12}{|c|}{ Morphine plus pretreaiment with cimctidine ${ }^{\dagger}$} \\
\hline \multirow[t]{2}{*}{$\left(\mathrm{L} \cdot \mathrm{min}^{-1} \cdot \mathrm{kPa}^{-1} \cdot \mathrm{m}^{-2}\right)$} & 9.8 & 6.0 & 5.3 & 5.3 & 6.0 & 5.3 & 5.3 & 5.3 & 6.0 & 7.5 & 10.5 \\
\hline & \pm 0.8 & \pm 0.8 & $\pm=0.8$ & \pm 0.8 & \pm 0.8 & \pm 0.8 & \pm 0.8 & \pm 0.8 & \pm 0.8 & \pm 1.5 & \pm 0.8 \\
\hline \multirow[t]{2}{*}{$\left(\mathrm{L} \cdot \mathrm{min}^{-1} \cdot \mathrm{mmHg}^{-1} \cdot \mathrm{m}^{-2}\right)$} & 1.3 & $0.8^{*}$ & $0.7^{*}$ & $0.7^{*}$ & $0.8^{*}$ & $0.7^{*}$ & $0.7 *$ & $0.7^{*}$ & $0.8^{*}$ & 1.0 & 1.4 \\
\hline & \pm 0.1 & \pm 0.1 & \pm 0.1 & \pm 0.1 & $\pm 0,1$ & $=0.1$ & \pm 0.1 & \pm 0.1 & \pm 0.1 & \pm 0.2 & \pm 0.1 \\
\hline \multicolumn{12}{|l|}{ Cimetidine alone } \\
\hline \multirow[t]{2}{*}{$\left(\mathrm{L} \cdot \mathrm{min}^{-1} \cdot \mathrm{kPa}^{-1} \cdot \mathrm{m}^{-2}\right)$} & 9.8 & 8.3 & 9.0 & 9.0 & 9.8 & 10.5 & 9.0 & 10.5 & 11.3 & 9.8 & 9.8 \\
\hline & \pm 1.5 & \pm 0.8 & \pm 1.5 & \pm 1.5 & $=1.5$ & $=1.5$ & \pm 1.5 & \pm 1.5 & \pm 2.3 & \pm 1.5 & \pm 0.8 \\
\hline \multirow[t]{2}{*}{$\left(\mathrm{L} \cdot \mathrm{min}^{-1} \cdot \mathrm{mmHg}^{-1} \cdot \mathrm{m}^{-2}\right)$} & 1.3 & 1.1 & 1.2 & 1.2 & 1.3 & 1.4 & 12 & 1.4 & 1.5 & 1.3 & 1.3 \\
\hline & \pm 0.2 & \pm 0.1 & \pm 0.2 & \pm 0.2 & \pm 0.2 & \pm 0.2 & \pm 0.2 & \pm 0.2 & \pm 0.3 & \pm 0.2 & \pm 0.1 \\
\hline
\end{tabular}

All values means \pm S.E.M.

*Significantly different from control (time 0 ) ( $p<0.05$, Dunnett's Test)

† Significantly different from cimetidine alone ( $p<0.05$, analysis of variance).

measurement period was demonstrated $(p<0.05$ ). There was no difference in end-tidal $\mathrm{CO}_{2}$ at any study period.

Changes in ventilation, $\mathrm{PETCO}_{2}$ and the ventilatory response to added carbon dioxide during the recovery period of $480,600,720$ minutes and 24 hours are shown in Figure 2. An apparent difference between morphine and morphine-cimetidine was evident until the end of 24 hours.

Compared to morphine alone, the morphine- cimetidine combination consistently yielded higher serum morphine concentrations at each time period, but there was no significant difference between the concentration or the regression slope (Figure 3).

\section{Discussion}

Cimetidine was approved initially primarily for the treatment of duodenal ulcers and hypersecretory syndromes. ' However, because of its overall effectiveness in reducing gastric acid production, it now 


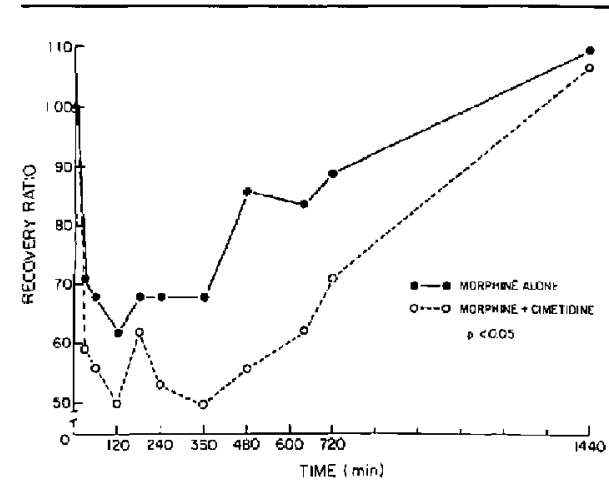

FIGURE 1 Recovery of the ventilatory response to added $\mathrm{CO}_{2}$ in the two study states (I and II). Recovery ratio of $\mathrm{CO}_{2}$ response slope is plotted on the vertical axis against time on the horizontal axis. morphine alone; $\mathrm{O}-\mathrm{O}$ morphine-cimetidine combination. Difference between the two states was statistically significant between the recovery period of 240-720 minutes.

has been used therapeutically for all disorders related to gastric acidity. Two recent surveys of use of cimetidine in hospitals have confirmed this wide application. ${ }^{14,15}$ Moreover, its effectiveness in lowering gastric acidity has also been repeatedly demonstrated in patients presenting for surgery. ${ }^{2-4}$ Therefore, an anaesthetist can encounter patients on cimetidine therapy in two ways: the patient can be on chronic cimetidine therapy for a specific gastric condition, or the patient can be pre-medicated with cimetidine prophylactically to minimize the risk of acid aspiration. While initially cimetidine was reported to be free of side-effects, recent investigations have demonstrated the possibility of important drug interactions as a result of cimetidine-induced changes in hepatic blood flow and the microsomal enzyme system. Chronic cimetidine therapy can reduce hepatic blood flow by 33 per cent and with acute administration by 25 per cent. ${ }^{5}$ This effect is felt to be important pharmacokinetically in the clearance of drugs primarily dependent on hepatic blood flow for removal from the circulation. Such an interaction has been demonstrated with intravenous administration of propranolol. ${ }^{5}$ On the other hand, inhibition of the microsomal enzyme system has been shown to increase as well as prolong the effect of warfarin. ${ }^{16}$ In addition to propranolol, drugs that depend on hepatic clearance include lidocaine and morphine. Indeed, cimetidine therapy has also been shown to reduce lidocaine clearance ${ }^{17}$ Cimetidine therefore can potentially decrease morphine clearance, thus exaggerating the accompanied respiratory depression. We attempt to clarify the significance of this interaction by studying the effect of acute cimetidine pre-treatment on morphineinduced respiratory depression. The dose of cimetidine was chosen to imitate what has been used for pre-medication and what can theoretically reduce hepatic blood flow by 25 per cent. Since the respiratory effects of cimetidine alone have not been well studied, we studied the subjects in an identical fashion with cimetidine $600 \mathrm{mg}$ alone.

Cimetidine alone had no significant respiratory effects with unchanged end-tidal $\mathrm{CO}_{2}$ and normal $\mathrm{CO}_{2}$ response. There was a transient, albeit not statistically significant, reduction in resting ventilation and the mechanism for this was not apparent, as no sedative effect was experienced by any of the subjects. This could conceivably represent a placebo effect. As expected, morphine reduced resting ventilation, elevated end-tidal carbon dioxide, shifted the $\mathrm{CO}_{2}$ response curve to the right and reduced its slope. The addition of cimetidine pre-medication appeared to exaggerate and prolong this respiratory depression, but its effect on the respiratory variables was not uniform. With regard to resting ventilation, there was a small but significant difference between morphine alone and morphine-cimetidine combination. While it is possible that the initial difference was due to the transient effect of cimetidine alone rather than to interaction between cimetidine and morphine, this would not explain the difference observed in the recovery phase. However, this difference must also be interpreted in light of the fact that the mean resting ventilation was lower at time 0 on the day that the morphine-cimetidine combination was studied. With the ventilatory response to added carbon dioxide, the morphine-cimetidine combination, when compared to morphine alone, caused a more profound reduction in the slope which lasted longer and full recovery did not occur until the end of 24 hours. The difference during the recovery period of 240 to 720 minutes was statistically significant $(p<0.05)$ (Figure 1 ). As no study was carried out between 720 minutes and the end of 24 hours, recovery conceivably could have occurred before the 24th hour. Interestingly, despite these effects on resting ventilation and the ventilatory 


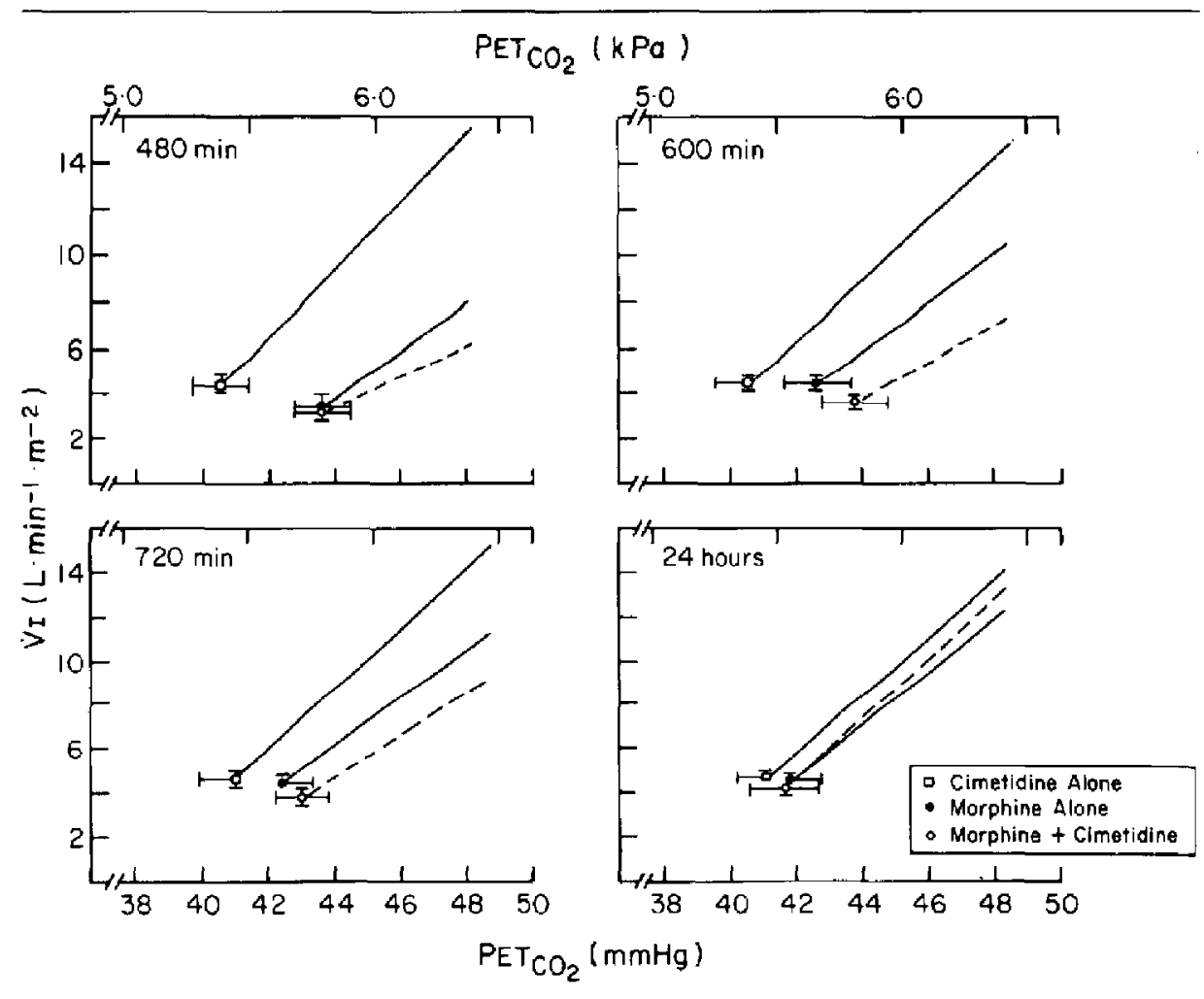

FIGURE 2 Ventilation, $\mathrm{PeTCO}_{2}$ and the ventilatory responses to added carbon dioxide at time $480,600,720$ minutes and 24 hours: $\square$ cimetidine alone; morphine alone; $O$ morphine-cimetidine. The points with SEM bars represent resting values of ventilation and $\mathrm{PETCO}_{2}$, and the lines extending from them represent the calculated carbon dioxide response slopes. An apparent difference between morphine and morphine-cimetidine is visible unti] the end of 24 hours.

response to added $\mathrm{CO}_{2}$, no significant difference in end-tidal $\mathrm{CO}_{2}$ could be demonstrated at any time period. Thus, one would have to conclude that the interaction, though present, has a minimal clinical effect in healthy subjects.

The demonstrated increase in respiratory depression did not correlate with serum morphine concentration as no significant difference in morphine concentration or its rate of decline between the two study states (I and II) could be demonstrated (Figure 3). This lack of appreciable pharmacokinetic interaction between cimetidine and morphine is consistent with a recent report on the effect of cimetidine on the pharmacokinetics of morphine in man. ${ }^{18}$ This observation, however, does not entirely disprove the proposed mechanism of the respiratory interac- tion. It is well recognized that serum morphine concentration correlates poorly with the magnitude of respiratory depression. ${ }^{19}$ Thus, it is conceivable that the small difference in serum morphine concentration between the two study states, particularly during the early measurement periods, has allowed an increased circulation of morphine to the respiratory control area of the brain to cause a more profound depression in the ventilatory response to hypercapnia. This is supported by the fact that all subjects (including four who were studied in a doubleblind fashion) experienced increased drowsincss with the morphine-cimetidine combination. A central additive effect is unlikely as no subject experienced scdation with cimetidine alone. A pharmacodynamic interaction cannot be ruled out as little is 


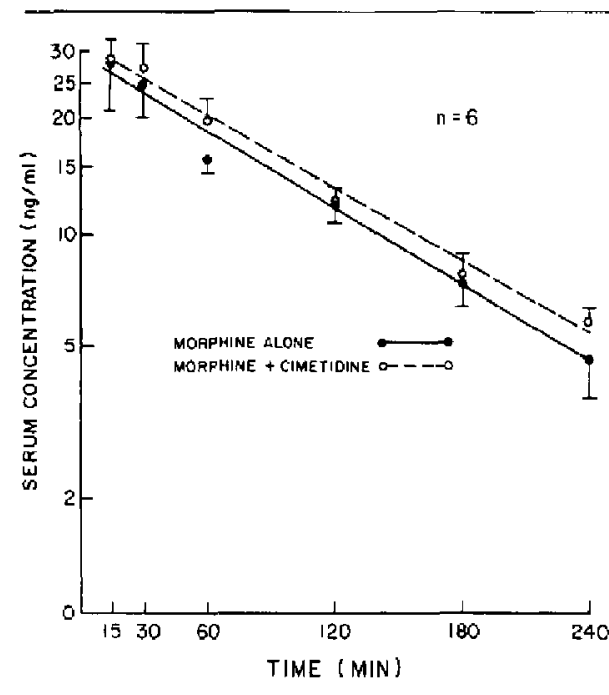

FIGURE 3 Change of serum morphine concentration with time in the two study states (I and II). Serum concentration of morphine is plotted on the vertical axis against time on the horizontal axis. _-_ morphine alone; O-..... O morphinecimetidine combination. Slope of the linear regression reprcsents rate of decline. Despite the apparent difference in serum morphine concentration between the two stales, there was no significant difference between the concentrations or the slopes.

known about the cross-reactivity of histamine and opiate receptors in the brain. Regardless of its nature, whether this interaction also potentiates the analgesic effect of morphine remains to be investigated.

Results of this study would indicate that cimetidine can potentiate morphine-induced respiratory depression but the magnitude of this potentiation is likely small and clinically insignificant in healthy individuals. This interaction, however, may well be amplified in patients with pre-existing breathing disorders, as in patients with severe chronic obstructive lung disease, or in patients who have received other centrally depressant drugs such as potent anaesthetic agents. Moreover, chronic cimetidine therapy will potentially increase the magnitude of this interaction. Therefore, although acute cimetidine premedication is unlikely to interact with opiates to cause profound respiratory depression, the anaesthetist should be cognizant of this potential complication in susceptible patients.

\section{Acknowledgements}

The authors thank the volunteers for their participation, Dr. M. Hirst and Mr. M. Adams for the morphine assay, Dr. G. Wells for statistical analysis, Drs D.C. Chung and B.J. Mezon for their advice, and Mrs. L. Nolan for secretarial assistance. In particular, Dr. R.L. Knill's guidance is greatly appreciated.

\section{References}

1 Finkelstein $W$, Isselbacher $K J$. Cimetidine. N Eng J Med 1978; 299: 992-6.

2 Coombs $D W$, Hooper $D$, Collon $T$. Acid-aspiration prophylaxis by use of preoperative oral administration of cimetidine. Anesthesiology 1979; 51: 352-6.

3 Kirkegaard $P$. Sorensen $O$, Kirkegaard $P$. Cimetidine in the prevention of acid aspiration during anesthesia. Acta Anaesthesiol Scand 1980; 24: 58-60.

4 Pickering BG, Palahniuk RJ, Cumming $M$. Cimetidine premedication in elective cacsarean section. $C$ an Anaesth Soc J 1980; 27: 33-5

5 Feely J, Wilkinson GR, Wood AJJ. Reduction of liver blood flow and propranolol metabolism by cimetidine. N Eng J Med 1981; 304: 692-5.

6 Puurunen J, Pelkonen $O$. Cimetidine inhibits microsomal drug metabolism in the rat. Eur J Pharmacol 1979; 55: 335-6.

7 Desmond PV, Parwardhan RV, Schenker S, Speeg KV. Cimetidine impairs elimination of chloridazepoxide (librium) in man. Ann Int Med 1980; 93: 266-8.

8 Klotz U, Reimann 1. Delayed clearance of diazepam due to cimetidine. N Engl J Med 1980; 302: 1012-4.

9 Jackson JE, Powell JR, Wandell $M$, Bentley J, Dorr $R$. Cimetidine decreases theophylline clearance. Am Rev Respir Dis 1981; 123: 615-7.

10 Stanski $D R$, Greenblatt DJ, Lowenstein E. Kinetics of intravenous and intramuscular morphine. Clin Pharmacol Ther 1978; 24: 52-9.

11 Lam AM. Potentially lethal interaction of cimetidine and morphine. Can Med Assoc J 1981; 125: 818 .

12 Lam AM, Clement JL, Chung DC, Knill RL. Respiratory effects of nitrous oxide during enflurane anesthesia in humans. Anesthesiology 1982; 56: 298303.

13 Sahn SA, Zwillich CW, Dick N, McCullough RE, Lakshminarayan $S$, Weil IV. Variability of ventilatory responses to hypoxia and hypercapnia. J Appl Physiol 1977; 43: 1019-25. 
14 Cocco $A E$, Cocco DV. A survey of cimetidine prescribing. N Engl J Med 1981; 304: 1281

15 Schade RR, Donaldson RM, Ir. How physicians use cimetidine. A survey of hospitalized patients and published cases. N Engl J Med 1981; 304: 1281-4.

16. Sertin MJ, Mossman S, Sibeon RG et al. Cimetidine: Interaction with otal anticoagulants in man. Lancet 1979; 2: 317-9.

17 Feely $d$. . Wilkinson GR, McAllister CD, Wood AJJ Increased toxicity and reduced clearance of lidocaine by cimetidine. Ann Intern Med 1982; 96: 592-4

18 Mojaverian $P$, Fedder IL, Vlasses $P H$ er al. Cinetidine does not alter morphine disposition in man. $\mathrm{Br} \mathrm{J}$ Clin Phamacol 1982; 14: 809-13.

19 Rigg JRA. Ventilatory effects and plasma concentration of morphine in man. Br J Anaesth 1978; 50: $759-65$.
Résumé

On a étudié la possibilité de l'influence sur le système respiratoire par interacrion de la morphine et de la cimétidine en déterminant la ventilation de repos, la pression partielle de $\mathrm{P}_{\mathrm{ET}} \mathrm{CO}_{2}$ expirée en fin d'expiration et la réponse ventilutoire au $\mathrm{CO}_{2}$ chez huit volontaires sains dans trois conditions différentes:

1) Cimétidine $600 \mathrm{mg}$ par la bouche,

2) Morphine $10 \mathrm{mg}$ intramusculaire,

3) Ciméridine $600 \mathrm{mg}$ par la bouche suivie de morphine $10 \mathrm{mg}$ intramusculaire.

Les effets se déroulaient dans un ordre déterminé de façon aléatoire et chaque séance était espacée d'au moins une semaine. Les mesures ont été effectuées au temps 0 , $30,60,120,180,240,360,480,600,720$ minutes et après 24 heures. De plus, le taux plasmatique de morphine a été mesuré chez six sujets durant les six premières heures après l'adninistration.

La cimétidine seule a des effets respiratuires négligeubles; lo morphine seule a réduit la ventilation de repos, élevé la PeTCO $\mathrm{O}_{2}$ en fin d"expiration et diminué la réponse ventilatoire au $\mathrm{CO}_{z}$ i pour sa part, la combinaison morphine/cimétidine a causé une dépression plus marquée de la réponse au $\mathrm{CO}_{2}$ et un retour à la normale plus lent. La ventilation de repos et la $\mathrm{PETCO}_{2}$ en fin d'expiration n'on pas montré de différence significative.

Nous concluons que la prémédication avec la cimétidine prolonge la dépression respiratoire causée par la morphine, mais l'importance de cette interaction est faible el ciniquement non significalive chez des sujets sains. Cependant, an devrait agir avec prudence chez certains malades plus susceptibles. 